\title{
Genetic models of C9orf72: What is toxic?
}

Thomas G. Moens ${ }^{1,2}$, Linda Partridge ${ }^{2,3}$, Adrian M. Isaacs ${ }^{1^{*}}$

1. Department of Neurodegenerative Disease, UCL Institute of Neurology, London WC1N 3BG, UK.

2. Department of Genetics, Evolution and Environment, Institute of Healthy Ageing, University College London, London WC1E 6BT, UK.

3. Max Planck Institute for Biology of Ageing, Robert-Koch-Str. 21, 50931 Cologne, Germany

*Corresponding Author: a.isaacs@.ucl.ac.uk

\section{Abstract}

A hexanucleotide repeat expansion in the gene C9orf72 is the most common genetic cause of both amyotrophic lateral sclerosis and frontotemporal dementia.

Pathogenesis may occur either due to loss of function of the C9orf72 gene, or a toxic gain of function, via the production of repetitive sense and antisense RNA and/or repetitive dipeptide repeat proteins. Recently, mouse knockouts have suggested that a loss of function of C9orf72 alone is insufficient to lead to neurodegeneration, whilst overexpression of hexanucleotide DNA is sufficient in a wide range of model systems. Additionally, models have now been created to attempt to study the effects of repetitive RNA and dipeptide proteins in isolation and thus determine their relevance to disease.

\section{Introduction}

A non-coding hexanucleotide repeat expansion in C9orf72 is the most common genetic cause of both frontotemporal dementia (FTD) and amyotrophic lateral sclerosis (ALS)[1,2]. The mutation is a (GGGGCC) ${ }_{n}$ expansion with unaffected individuals typically carrying fewer than 30 repeats, while patients harbour several hundreds to thousands[1-4]. Affected individuals present clinically with either ALS, FTD, or both $[1,2,5]$ and display TDP-43 pathology $[1,6]$. 
Three mechanisms have been proposed to explain how C9orf72 hexanucleotide expansions lead to ALS/FTD (C9ALS/FTD), either by loss-of-function or by two different gain-of-function mechanisms (Figure 1A-C):

(1) The expansion leads to reduced transcription of C9orf72, leading to haploinsufficiency (Figure 1A).

(2) Repeat-containing sense and antisense RNA transcripts accumulate and sequester RNA binding proteins (Figure 1B).

(3) Sense and antisense RNA are translated by repeat-associated, non-ATG initiated (RAN) translation into five, potentially toxic, repetitive dipeptide proteins (DPRs) (Figure 1C).

We will critically review newly developed cellular and animal C9FTD/ALS models and discuss the insight they provide into the role of each proposed mechanism in disease pathogenesis.

\section{Loss of function}

C9orf72 has three splice variants that either harbour the expansion in the first intron of the gene (variants 1 and 3) or the promoter (variant 2)[1]. Variant 1 comprises exons 1-5 and encodes a short protein isoform (222 amino acids: C9ORF72-S) while variants 2 and 3 encode the long isoform (481 amino acids: C9ORF72-L)[1,7].

Analysis of post mortem C9ALS/FTD brains showed reduced C9orf72 transcript $[1,8-$ $13]$ and reduced protein[ $[7,11,14]$. This may be a consequence of epigenetic silencing[8,10,15,16] or abortive transcription[17]. Reduced C9orf72 levels in patients led to the suggestion that loss of normal C9orf72 function leads to pathogenesis. However, only a single sporadic ALS patient has ever been found to carry a mutation potentially capable of causing a heterozygous loss of function, and it is unclear if this mutation is causative of the disease state[18,19]. Additionally, a patient homozygous for the repeat expansion had a similar clinical phenotype to heterozygote patients, rather than a much more severe phenotype typical of homozygous loss of function mutations[12]. Therefore the genetic evidence currently supports a gain of function rather than a loss of function mechanism as the primary cause of disease [20]. However, loss of function models are providing evidence in favour of an important role for C9orf72 in cellular functions relevant to neuronal function, which suggests loss of function could contribute to the disease process. 
C9orf72 is homologous to members of the DENN (differentially expressed in normal and neoplastic cells) domain containing protein family, and is predicted to be involved in membrane trafficking as a Rab guanine exchange factor[21]. C9ORF72-L forms a complex with SMCR8 and WDR41[22-27] and is involved in the induction of autophagy[22,23,25,28,29], whilst C9ORF72-S is localised at the nuclear membrane in patient brain and has been suggested to be involved in nucleocytoplasmic transport[7]. Work in cell lines or primary rodent neuronal cultures has demonstrated that knockdown of C9orf72 is sufficient to induce P62-positive puncta[23,28], consistent with autophagic dysfunction, and one study has observed the mislocalisation of phosphorylated TDP-43 after C9orf72 knockdown[23].

Several animal models have been produced in which the expression of genes orthologous to C9orf72 are reduced (Table 1, Figure 1D). Knockout of the C. elegans ortholog of C9orf72 (ALFA-1) led to progressive age-related paralysis[30]. Injection of antisense morpholino oligonucleotides during zebrafish development led to altered axonal branching in larval motor neurons and an associated motor phenotype[9]. Consistent with this finding, it was recently shown that $C 9$ orf72 regulates actin dynamics and axon growth in cultured motor neurons[14].

Several groups have tested the effect of reduced expression of the mouse ortholog of C9orf72 (3110043021Rik), either in a tissue-specific or ubiquitous manner (Table 1). The results of these studies are strikingly concordant; no overt neurodegeneration occurs in response to partial or complete loss of C9orf72 function. Furthermore, no mislocalisation of TDP-43 is observed[31-33]. These findings clearly suggest that loss of C9orf72 function is not sufficient to cause disease. Interestingly, however, whilst neuron-specific knockdown or knockout had no pathogenic effects[31,34], whole-genome knockout resulted in immune system phenotypes, including splenomegaly (enlarged spleen) and lymphandenomegaly (enlarged lymph nodes) $[25,33,35-37]$. These findings are particularly interesting given the increasing evidence supporting a role for the immune system in a wide range of neurodegenerative diseases[38]. 


\section{Gain of RNA and Protein Function}

\section{Gain of Function Pathologies}

A typical feature of many repeat expansion diseases is the formation of RNA foci: aggregates of RNA which are capable of sequestering RNA-binding proteins [39]. In C9ALS/FTD, repeat-expanded RNA is transcribed in both sense and antisense directions and forms both nuclear, and rarer, cytoplasmic sense and antisense RNA foci across multiple patient brain regions, and in patient derived cell lines (Figure 1B) [1,34,40-48]. Several studies have identified RNA-binding proteins (RBPs) sequestered by sense and antisense transcripts. Therefore reduced availability of these RBPs may play a role in the disease state (reviewed in [49]).

In addition to the formation of RNA foci, sense and antisense expansion-containing RNA is also RAN translated in all three reading frames, producing five, potentially toxic dipeptide-repeat proteins (DPRs)[43,50,51] (Figure 1C). DPRs form p62positive, TDP43-negative inclusions, abundant in the neocortex, hippocampus and cerebellum[50-52]. Typically, poly-GA inclusions are the most abundant, followed by poly-GP and poly-GR, whilst poly-AP and poly-PR inclusions are rare $[47,53,54]$. Pathological studies have examined DPR inclusions in C9FTD, C9ALS or C9FTD/ALS patients, and have not found consistent correlations between RAN protein pathology and clinical phenotype, TDP-43 pathology or neurodegeneration $[52,53,55]$. However, a recent study found that levels of soluble poly-GP in the cerebellum correlate positively with cognitive impairment [56].

\section{Pure GGGGCC repeat models}

In order to determine whether a gain of function is sufficient to induce a disease phenotype, several groups have overexpressed GGGGCC repeats and demonstrated deleterious phenotypes in cell culture [45,57-59], C.elegans [60] Zebrafish[45], and Drosophila[58,61-63] models, providing evidence that C9orf72 mutation associated toxic gain of function is sufficient to cause disease (Figure 1E).

Recently, several mouse models of C9orf72 expansions have been produced, either using overexpression of hexanucleotide repeats [64], or integration of human bacterial artificial chromosomes (BACs) containing expanded hexanucleotide DNA[35,37,66,67] (Table 2). Whilst all studies demonstrated that expression of 
repeat-expanded RNA led to foci formation, and resulted in at least some DPR species, the resultant phenotypes of the various mouse models were markedly different.

Overexpression of 66 GGGGCC repeats using adeno-associated viruses (AAVs) led to accumulation of RNA foci, DPR and TDP-43 pathology as well as neuronal loss with cognitive and motor dysfunction[64]. Generation of BAC mice led variously to: no cognitive or motor abnormalities[65,66], hippocampus-related cognitive dysfunction[37] or either acute or progressive phenotypes marked by behavioural and motor abnormalities and reduced survival[67]. The discrepancies between these outcomes seem unlikely to be due to differences in the amount of 5' or 3' C9orf72 flanking sequence present in each BAC, as the BACs from phenotypic and nonphenotypic mice overlapped (Table 2). It is notable that the different models were produced in different genetic backgrounds (Table 2), which can strongly influence neurodegenerative phenotypes in mice [68]. Additionally, toxicity may be dependent on level of expression. For example, Chew et al. (2015) [64] and Liu et al. (2016) [67] found that strong overexpression of relatively short repeat lengths to be toxic, whilst Jiang et al. (2016) [37] found that foci formation and DPR accumulation were positively correlated with repeat-expansion-containing RNA expression levels. It is thus possible that the required level of putatively toxic RNA or DPR species was not met in non-phenotypic mice.

Despite these differences, the fact that expression of hexanucleotide RNA can lead to behavioural and motor abnormalities underpinned by neurodegeneration, especially in a BAC context where expression is driven by the endogenous C9orf72 promoter, strongly suggests that a gain of function alone is sufficient to drive pathogenesis. It is notable that phenotypic mice either displayed TDP-43 inclusions [64,67] or increased TDP-43 phosphorylation[37], providing further evidence that neurodegeneration is driven primarily through a toxic gain of function leading to TDP-43 pathology. 


\section{RNA or Protein?}

Whilst pure GGGGCC repeat expression models provide evidence of a toxic gain of function, they cannot distinguish whether toxicity is primarily mediated by RNA or DPRs, which has led to considerable debate in the field.

\section{RNA-only models}

In order to study the potential role of RNA toxicity in isolation, it is necessary to design models where GGGGCC repeat containing RNA is expressed whilst RAN translation is suppressed. GGGGCC repeat RNA (36 and 103 repeats) is toxic to Drosophila neurons when overexpressed. Conversely, when the repeats are interrupted by regularly interspersed stop codons in every reading frame RAN translation and toxic phenotypes are completely prevented, even when up to $\sim 288$ interrupted repeats are expressed[61,69]. This suggests that DPRs are the major contributor to toxicity in Drosophila models of C9orf72. In concordance with this conclusion, overexpression of sense hexanucleotide RNA from the intron of a transgene in Drosophila is sufficient for the formation of numerous RNA foci but does not cause toxicity, because efficient splicing of intronic repeat RNA prevents its nuclear export and RAN translation[70] (Figure 1F).

Interestingly, in a BAC mouse model, the presence of multiple copies of short repeat lengths (29-36 repeats) produced only DPRs and not nuclear RNA foci, but TDP-43 pathology and neurodegenerative phenotypes were still observed[67](Table 2). Together these results suggest that RNA foci are dispensable for the induction of disease pathogenesis in Drosophila and mice. However, it is difficult to rule out a possible toxic effect of RNA that does not form foci, or cytoplasmic RNA, a prospect that has recently been raised in iPSC-derived neurons[63].

On the other hand, a different Drosophila model carrying an inducible construct capable of expression of 30 hexanucleotide repeats interrupted by a 6-base pair restriction endonuclease cut site[58] does not produce detectable DPRs when expressed in photoreceptor neurons or pan-neuronally despite showing degenerative phenotypes, suggesting that toxicity in this model is primarily driven by RNA[71]. It should be noted however, that poly-GR becomes detectable upon strong overexpression in these flies, suggesting that there may be poly-GR present at 
undetectable levels, which may contribute to the observed phenotypes in lower expressing flies. Additionally, it has been shown that expression of 42 GGGGCC repeats from the intron of a transgene is toxic to mouse primary cortical and motor neurons, with the development of abundant RNA foci but no detectable DPR accumulation[59].

These results suggest that the potential toxicity of expanded RNA may depend on subcellular localisation and the model system employed. Additionally, no study has attempted to assess the effect of overexpression of antisense RNA in isolation. Thus, further characterisation of existing models as well as development of antisense models will be required to fully assess the contribution of RNA toxicity in C9ALS/FTD.

\section{Protein-only models}

Protein-only models include exogenous application of recombinant DPR peptides and the use of codon degeneracy (individual amino acids can be encoded by more than one triplet codon) to generate transgenic models that overexpress individual DPRs in an ATG-driven manner, allowing comparison of their relative effects (Figure 1G, Table 3). Although DPRs may be present at higher levels than those typically observed in patient tissue, there is a broad consensus across multiple model systems that arginine-rich DPRs (poly-GR and Poly-PR) are highly toxic (Table 3), with other dipeptide proteins, most notably poly-GA, being identified as toxic in some model systems $[61,72-75]$.

In order to determine mechanisms of DPR toxicity, several groups have attempted to identify arginine-DPR interacting proteins using immunoprecipitation of DPRs from cell lines with subsequent mass-spectrometric identification of interacting proteins[76-80]. Recently, two studies have demonstrated that arginine-rich DPR interactors are enriched in low complexity regions (LCRs), typically found in protein constituents of membrane-less organelles such as stress granules, nuclear speckles and nucleoli[79,80]. The exact mechanism(s) by which the arginine-rich DPRs are toxic to neurons are still not fully resolved, however translational repression[77,80], mitochondrial dysfunction[78], nucleolar dysfunction[76,81], and disruption of nucleocytoplasmic transport have all been implicated[62,71,82,83]. 
It should be noted that although poly-GA is seemingly less toxic than the arginine rich DPRs, it has been shown to exert mild toxicity when expressed in Drosophila neurons[61] and in cell culture, including primary rodent neurons[72-75]. Recently it was demonstrated that $A A V$-mediated overexpression of poly-GA dipeptides in mice led to neurodegeneration and, cognitive and motor dysfunction[74]. However, only rare TDP-43 inclusions were observed, indicating that accumulation of poly-GA protein alone may be insufficient to lead to the full disease state[74]. Future studies will be required to determine whether arginine-rich DPR overexpression is sufficient to induce ALS/FTD associated phenotypes in mice.

\section{Synergistic Mechanisms}

Although researchers have aimed to isolate different possible mechanisms of toxicity in order to elucidate their potential role in disease, it is possible that individual mechanisms act synergistically to induce the disease state.

Whilst loss of function of C9orf72 alone is unlikely to be sufficient to induce disease, cell culture studies suggest that reduced expression of C9orf72 leads to disruption of autophagy $[22,23,28,29]$ and autophagic dysfunction has been strongly linked to neurodegenerative disease [84]. Therefore the potential role of C9orf72 loss of function as a disease modifier should be thoroughly explored. Recently it was demonstrated that overexpression of C9orf72 reduces the aggregation of TDP-43 in cell culture and a small decrease in C9orf72 expression exacerbated expanded ataxin-2 pathology in mouse neurons and zebrafish larvae[23]. The genetic models described above, such as knockout mice and mice transgenic for hexanucleotide expansions can now be combined to ascertain the degree to which C9orf72 loss of function may affect disease phenotypes.

Arginine-rich DPRs are toxic in multiple systems whilst poly-GA has also been shown to be toxic to mouse neurons. Interestingly, poly-GA has been demonstrated to recruit poly-GR into inclusions when co-expressed in human cells [85] and in Drosophila, resulting in a lessening of poly-GR toxicity [86]. Whether interaction between the individual DPRs acts to enhance or suppress their toxicity is thus a point of interest. Additionally, frameshifting during the translation of repetitive proteins has been described in other repeat expansion disorders[87]. Whether this occurs in 
C9orf72 mutation carriers is currently unknown, but could potentially lead to the production of peptides imbued with the qualities of more than one DPR species.

\section{Conclusions}

Recent studies of the mechanism(s) of pathogenesis in C9ALS/FTD have focused on attempting to separate potential pathologies in model systems to study them further. Although the C9ORF72-L protein has been implicated in the induction of autophagy, a number of mouse loss of function models have failed to develop ALS/FTD associated phenotypes (Table 1). Expression of expanded GGGGCC repeat DNA is extremely toxic in a number of model systems. Recent advances include the expression of GGGGCC repeat DNA in mice, which under some circumstances display motor dysfunction and behavioural abnormalities with TDP-43 pathology (Table 2). Despite the potential shortcomings of the model systems in question, for example the incomplete homology of disrupted orthologous genes (see Table 1), or the strong overexpression of relatively short repeat lengths employed in many models, in combination these results strongly indicate that expression of expanded GGGGCC repeats alone are sufficient to cause C9ALS/FTD.

Although it seems likely that the C9orf72 repeat expansions cause toxicity through a gain of function it is not clear whether this is primarily mediated by expanded RNA or DPR proteins. Several groups have attempted to separate RNA expression from DPR production, with clear evidence, albeit in Drosophila models, indicating that repeat RNA without the expression of dipeptide proteins may not be toxic. Others have studied the relative toxicity of different DPR species by overexpressing recodonised protein constructs (Table 3 ) and overexpressed arginine-containing DPRs have been repeatedly independently identified as being toxic. However, overexpression of poly-GA is sufficient to induce neurodegeneration in mice, leaving the relative contribution of different dipeptides to the toxicity demonstrated in mouse models currently unresolved. It will be important to develop models with physiological expression levels of the DPRs in order to accurately tease out the contribution of each DPR to neuronal dysfunction. It is also likely that the different potential mechanisms of toxicity interact in bringing about the disease state. Thus, although individual DPRs and hexanucleotide containing RNA have the potential to be toxic, the combination of individual, physiological genetic models will be crucial in understanding how these pathologies interact and ultimately lead to the full disease state. 


\section{Potential toxic mechanisms}

A Happloinsufficiency

C9orf72 gene

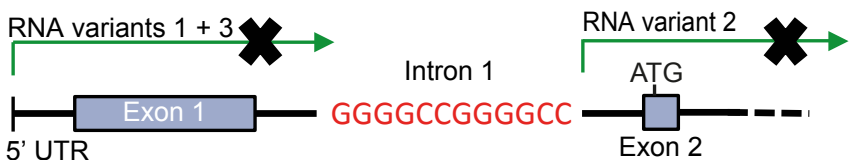

5' UTR

Exon 2

B RNA toxicity

Sense RNA

Expanded sense RNA
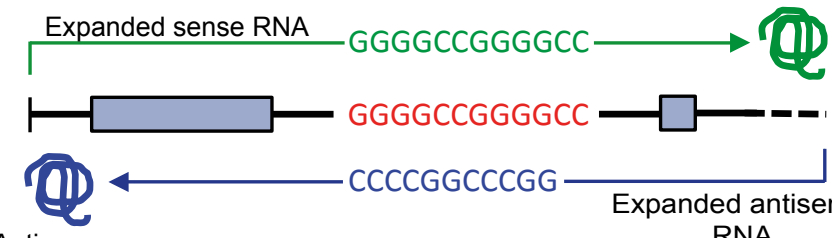

Antisense

Expanded antisense RNA foc

\section{Dipeptide toxicity}
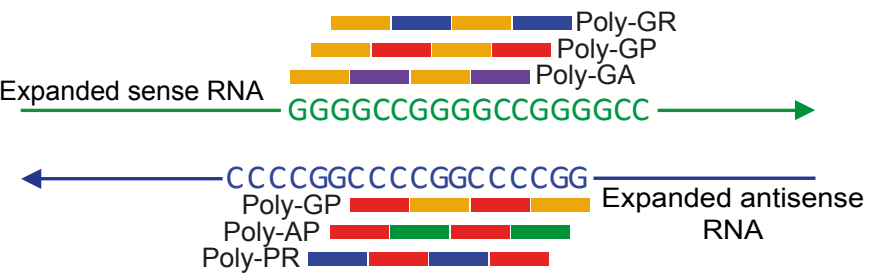

$\underline{\text { Common genetic models }}$

D Knockout / knockdown

Disruption of orthologous genes

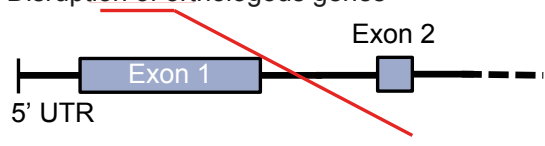

E Transgenic expression

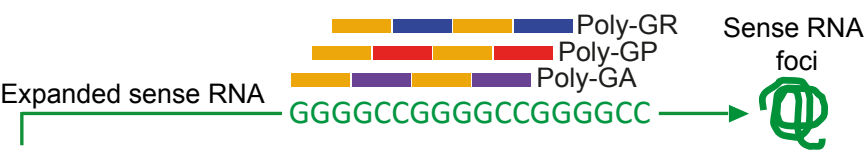

$F$

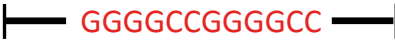

Transgene

Disruption of RAN translation

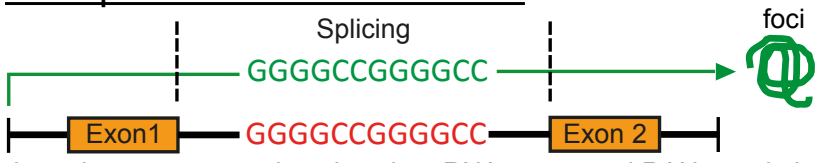

Intronic transgene: reduced nuclear RNA export and RAN translation

-GGGGCC-STOP-GGGGCC (1)

GGGGCC-STOP-GGGGCC
Stop codon interrupted repeat transgene

G

Recodonised Dipeptide Expression

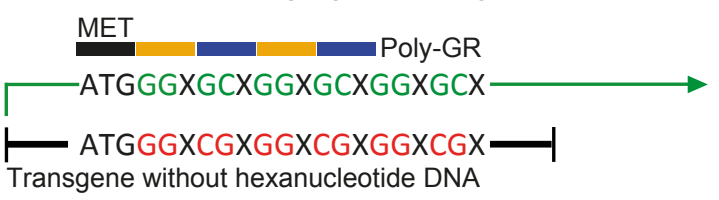

Figure 1: Potential mechanisms of $\mathrm{C9}$ orf72 hexanucleotide expansion toxicity and commonly employed genetic models. Three potential mechanisms by which the C9orf72 associated hexanucleotide expansioncauses toxicity. A) Epigenetic silencing associated with the repeat expansion leads to reduced C9orf72 expression and thus happloinsufficiency. B) The hexanucleotide expanded DNA is transcribed in both sense and antisense directions. These expanded RNAs form typically, intranuclear aggregates known as RNA foci, which have been proposed to sequester RNA binding proteins leading to toxicity. C) Repeat expanded RNAs can undergo repeat-associated-non-ATG-initiated (RAN) translation producing repetitive peptides from all reading frames without the requirement of an ATG start codon[57]. RAN translation of both sense and antisense RNA has been demonstrated to occur in C9ALS/FTD patients, leading to the production of five potentially toxic dipeptide repeat proteins (DPRs), these are: poly-glycine-alanine (poly-GA), poly-glycine-proline (poly-GP), poly-glycine-arginine (poly-GR), poly-alanine-proline (polyAP), and poly-proline-arginine (poly-PR). D) Loss of function of C9orf72 or its orthologous genes in other species can be used to study whether a complete or partial loss of C9orf72 in isolation is sufficient to induce a disease phenotype (see Table 1) E) Transgenic overexpression of GGGGCC repeats, either on their own or as part of a patient derived bacterial artificial chromosome (BAC), model both RNA and DPR toxicity, an approach that has recently been applied to generate mouse models of the disease (Table 2). F) Two approaches have been used to suppress RAN translation and study the effect of hexanucleotide repeat expression in isolation, either expression of relatively short stretches of GGGGCC repeats from within a strongly constitutively spliced intronic region[59,70] or by regularly interrupting the repeat sequence with stop codons[61]. G) Codon degeneracy allows for the engineering of "recodonised" constructs that allow ATG-initiated expression of individual dipeptide repeat proteins without an underlying GGGGCC repeat sequence (Table 3). 


\begin{tabular}{|c|c|c|c|c|}
\hline Model Organism & Orthologue (\%protein identity) & Intervention & Phenotype & Study(s) \\
\hline C.elegans & ALFA-1 $(23.6 \%)$ & Knockout/RNAi silencing & $\begin{array}{l}\text { Enhanced age-related paralysis phenotype. } \\
\text { GABAergic neuronal dysfunction }\end{array}$ & Therrien et al. (2013) [30] \\
\hline D.rario & zC9orf72 (76.1\%) & $\begin{array}{l}\text { Antisense morpholino injection into } \\
\text { fertilized eggs }\end{array}$ & $\begin{array}{l}\text { Shortened motor neuron axons, deficits in } \\
\text { evoked and spontaneous swimming in } \\
\text { larvae }\end{array}$ & Ciura et al. (2013) [9] \\
\hline \multirow[t]{9}{*}{ M.musculus } & \multirow[t]{9}{*}{ 3110043O21Rik (98.1\%) } & $\begin{array}{l}\text { Intraventricular injection of antisense } \\
\text { oligonucleotides against C9orf72 }\end{array}$ & $\begin{array}{l}\text { No behavioural or motor differences. No } \\
\text { evidence of TDP- } 43 \text { pathology. }\end{array}$ & Lagier-tourenne et al. (2013) [34] \\
\hline & & $\begin{array}{l}\text { Cre-lox mediated brain specific excision of } \\
\text { exons } 4-5\end{array}$ & $\begin{array}{l}\text { In both heteroyzgous and homozygous } \\
\text { animals: No alteration in lifespan or grip } \\
\text { strength. No evidence of TDP- } 43 \text { pathology } \\
\text { or neurodegeneration. }\end{array}$ & Koppers et al. (2015) [31] \\
\hline & & $\begin{array}{l}\text { Transgenic mice with replacement of } \\
\text { exons 2-11 with LacZ construct }\end{array}$ & $\begin{array}{l}\text { Reduced motor function in homozygous } \\
\text { knockouts. Evidence of immune } \\
\text { dysregulation. No overt neurodegeneration. }\end{array}$ & Atanasio et al. (2016) [37] \\
\hline & & $\begin{array}{l}\text { Transgenic mice with replacement of } \\
\text { exons } 2-6 \text { with LacZ construct }\end{array}$ & $\begin{array}{l}\text { Reduced lifespan in both heterozygote and } \\
\text { homozygote knockouts. Evidence of } \\
\text { immune dysregulation. No evidence of } \\
\text { neurodegeneration. }\end{array}$ & $\begin{array}{l}\text { Suzuki et al. (2013) [87]; } \\
\text { Burberry et al. (2016) [35] }\end{array}$ \\
\hline & & $\begin{array}{l}\text { CRISPR-cas9 targeted disruption of exon } \\
4\end{array}$ & $\begin{array}{l}\text { Reduced survival in mosaic heterozygous } \\
\text { and compound heterozygous mutants. } \\
\text { Evidence of immune dysfunction. }\end{array}$ & Burberry et al. (2016) [35] \\
\hline & & $\begin{array}{l}\text { Transgenic mice with replacement of } \\
\text { exons } 2-6 \text { with LacZ construct }\end{array}$ & $\begin{array}{l}\text { Reduced lifespan in homozygous } \\
\text { knockouts. Some mild beahvioural and } \\
\text { motor dysfunction. Evidence of immune } \\
\text { dysregulation. No overt neurodegeneration. }\end{array}$ & Jiang et al. (2016) [36] \\
\hline & & $\begin{array}{l}\text { Transgenic mice with replacement of } \\
\text { exons 2-6 with LacZ construct } \\
\text { Zinc finger nuclease mediated removal of } \\
\text { exon } 2 \text { start codon }\end{array}$ & $\begin{array}{l}\text { No behavioral or motor differences. } \\
\text { Evidence of immune dysfunction. No } \\
\text { evidence of TDP- } 43 \text { pathology or } \\
\text { neurodegeneration. }\end{array}$ & O'Rourke et al. (2016) [33] \\
\hline & & $\begin{array}{l}\text { Cre-lox mediated whole-genome specific } \\
\text { excision of exons } 4-5\end{array}$ & $\begin{array}{l}\text { Homozygous knockouts display reduced } \\
\text { survival. No evidence of motor } \\
\text { dysfunction. No evidence of TDP-43 } \\
\text { pathology or neurodegeneration. Evidence } \\
\text { of immune deregulation. }\end{array}$ & $\begin{array}{l}\text { Koppers et al. (2015) [31]; Sudria } \\
\text { Lopez et al. (2016) [32] }\end{array}$ \\
\hline & & $\begin{array}{l}\text { CRISPR-cas } 9 \text { mediated frameshift } \\
\text { mutation in exon } 2 \text { causing premature } \\
\text { stop codon affecting variants } 1 \text { and } 3 .\end{array}$ & Evidence of immune dysregulation & Sullivan et al. (2016) [25] \\
\hline
\end{tabular}

Table 1: Comparison of loss of animal studies examining phenotypic effects of loss of function of C9orf72 orthologs. 


\begin{tabular}{|c|c|c|c|c|c|c|c|c|c|c|c|c|c|c|}
\hline \multirow[b]{2}{*}{\begin{tabular}{|l|} 
Type of \\
Transgenic
\end{tabular}} & \multirow[b]{2}{*}{ Transgene Information } & \multirow[b]{2}{*}{ Repeat Length } & \multirow[b]{2}{*}{$\begin{array}{l}\text { Genetic } \\
\text { Background }\end{array}$} & \multirow[b]{2}{*}{ Phenotype } & \multicolumn{2}{|c|}{ Foci Pathology } & \multicolumn{5}{|c|}{ Dipeptide Pathology } & \multirow[b]{2}{*}{$\begin{array}{c}\text { TDP-43 } \\
\text { Inclusions }\end{array}$} & \multirow[b]{2}{*}{ Neurodegeneration } & \multirow[b]{2}{*}{ Study } \\
\hline & & & & & Sense & Antisense & GP & GA & GR & PA & PR & & & \\
\hline $\begin{array}{l}\text { AAV based } \\
\text { overexpression } \\
\text { with CMV } \\
\text { promoter. }\end{array}$ & $\begin{array}{l}\text { CMV promoter. } \\
\text { Intracerebroventricular } \\
\text { injection at P0. Repeats } \\
\text { cloned with 119bp 5' } \\
\text { flanking region and } 100 \mathrm{bp} \\
3^{\prime} \text { flanking region of the } \\
\text { C9orf72 gene }\end{array}$ & 66 repeats & C57BL/6J & $\begin{array}{l}\text { Male mice examined. } 66 \text { repeat } \\
\text { expressing mice demonstrate } \\
\text { behavioural and motor } \\
\text { abnormalities. }\end{array}$ & $x$ & $?$ & $\mathbf{x}$ & $\mathbf{x}$ & $x$ & $?$ & $?$ & $\mathbf{x}$ & Severe & $\begin{array}{l}\text { Chew et al. }(2015 \\
\text { [64] }\end{array}$ \\
\hline $\begin{array}{l}\text { Human } \\
\text { C9orf72 BAC }\end{array}$ & $\begin{array}{l}\text { BAC containing full } \\
\text { C9orf72 gene region } \\
\text { ( } \sim 36 \mathrm{~kb}) \text { with } \sim 110 \mathrm{~kb} \\
\text { upstream and } \sim 20 \mathrm{~kb} \\
\text { downstream }\end{array}$ & $\begin{array}{l}\text { Unknown copy number; } \sim 100-600 \text { repeats } \\
\text { (F112) } \\
\text { Unknown copy number; } \sim 100-1000 \\
\text { repeats (F113) } \\
\text { Unknown copy number; } 15 \text { repeats }\end{array}$ & C57BL/6J & $\begin{array}{l}\text { Male mice examined. No } \\
\text { behavioural or motor } \\
\text { abnormalities. }\end{array}$ & $\checkmark$ & $\times$ & $\checkmark$ & $?$ & $?$ & $?$ & $?$ & $\times$ & $\begin{array}{l}\text { None } \\
? \\
?\end{array}$ & $\begin{array}{l}\text { O'Rourke et al. } \\
\text { (2015) [65] }\end{array}$ \\
\hline $\begin{array}{l}\text { Human } \\
\text { C9orf72 BAC }\end{array}$ & $\begin{array}{l}\text { BAC containing } 140.5 \mathrm{~kb} \\
\text { upstream and exons } 1-5 \text { of } \\
\text { the C9orf72 gene }\end{array}$ & 2 copies; 300 repeats $/ 500$ repeats & SJL/B6 & $\begin{array}{l}\text { Male mice examined. No } \\
\text { behavioural or motor } \\
\text { abnormalities. No evidence of } \\
\text { neuronal dysfunction. }\end{array}$ & $\checkmark$ & $\checkmark$ & $\checkmark$ & $?$ & $?$ & $?$ & $?$ & $\mathbf{x}$ & None & $\begin{array}{l}\text { Peters et al. } \\
\text { (2015) [66] }\end{array}$ \\
\hline \multirow{3}{*}{$\begin{array}{l}\text { Human } \\
\text { C9orf72 BAC }\end{array}$} & \multirow{3}{*}{$\begin{array}{l}\text { BAC containing } 140 \mathrm{~kb} \\
\text { upstream and exons } 1-5 \text { of } \\
\text { the C9orf } 72 \text { gene }\end{array}$} & 1 copy; 450 repeats (high expression) & \multirow{3}{*}{$\begin{array}{l}\mathrm{C} 57 \mathrm{BL} 6 / \mathrm{CH} 3 \\
\text { injected, } \\
\text { backcrossed } \\
\text { into C57BL/6 }\end{array}$} & \multirow{3}{*}{$\begin{array}{l}\text { No motor abnormalities in any } \\
\text { tested line. Male but not female } \\
\text { medium and high } 450 \text { repeat } \\
\text { expressors display cognitive and } \\
\text { behavioural dysfunction. }\end{array}$} & $\checkmark$ & $\checkmark$ & $\checkmark$ & $\checkmark$ & $\checkmark$ & $x$ & $x$ & $x$ & Mild & \multirow{3}{*}{$\begin{array}{l}\text { Jiang et al. (2016) } \\
\text { [36] }\end{array}$} \\
\hline & & $\begin{array}{l}1 \text { copy; } 450 \text { repeats (medium expression) } \\
1 \text { copy; } 450 \text { repeats (low expression) }\end{array}$ & & & $\checkmark$ & $\checkmark$ & $\checkmark$ & $?$ & $?$ & $\mathbf{x}$ & $x$ & $\begin{array}{l}? \\
?\end{array}$ & $\begin{array}{l}\text { Mild } \\
?\end{array}$ & \\
\hline & & 1 copy; 110 repeats (medium expression) & & & $x$ & $x$ & $x$ & $?$ & $?$ & $x$ & $x$ & $?$ & None & \\
\hline \multirow[t]{2}{*}{$\begin{array}{l}\text { Human } \\
\text { C9orf72 BAC }\end{array}$} & \multirow[t]{2}{*}{$\begin{array}{l}\text { BAC containing full } 29.6 \mathrm{~kb} \\
\text { C9orf72 gene with } \sim 52 \mathrm{~kb} \\
\text { upsteam and } \sim 19.4 \mathrm{~kb} \\
\text { downstream sequence } \\
\text { ( } \sim 98 \mathrm{~kb} \text { total) }\end{array}$} & 4 copies: $36 / 29$ repeats & \multirow[t]{2}{*}{ FVB/NJ } & $\begin{array}{l}\text { Male and female mice examined. } \\
\text { Either acute phenotype, slower } \\
\text { progressive phenotype } \\
\text { (symptomatic mice), or } \\
\text { asymptomatic. Acute phenotype } \\
\text { characterised by reduced } \\
\text { survival. Symptomatic mice } \\
\text { display behavioural and motor } \\
\text { abnormalities. }\end{array}$ & $\mathbf{x}$ & $x$ & $\checkmark$ & $\checkmark$ & $?$ & $?$ & $?$ & $\checkmark$ & $\begin{array}{l}\text { Severe in acute } \\
\text { end stage animals. } \\
\text { Moderate in slow } \\
\text { progressive } \\
\text { animals. None in } \\
\text { asymtomatic } \\
\text { animals. }\end{array}$ & \multirow[t]{2}{*}{$\begin{array}{l}\text { Liu et al. (2016) } \\
\text { [67] }\end{array}$} \\
\hline & & 1 copy: 37 repeats & & $\begin{array}{l}\text { Male and female mice examined, } \\
\text { no phenotypes observed }\end{array}$ & $x$ & $x$ & $x$ & $x$ & $?$ & $?$ & $?$ & $x$ & None & \\
\hline
\end{tabular}

Table 2: Comparison of mouse models of C9orf72 repeat expansion.

$\checkmark=$ Detected, $X=$ Not detected, ?=Not examined

$\mathrm{x} \bullet$ Increased phospho-TDP43 observed by immunoblot vs non-transgenic, but no mislocalisation observed. 


\begin{tabular}{|c|c|c|c|c|c|c|}
\hline Study & Model system & GR & PR & GA & AP & GP \\
\hline Kwon et al. (2014) [80] & U2OS cells / human astrocytes & $20^{*}$ & $20^{*}$ & & & \\
\hline May et al. (2014) [72] & HEK293 cells & 149 & 175 & 175 & 175 & 80 \\
\hline Mizielinska et al. (2014) [61] & Drosophila & $36 ; 100$ & $36 ; 100$ & $36 ; 100$ & $36 ; 100$ & 50 \\
\hline Wen et al. (2014) [59] & Drosophila & & 50 & 50 & $25-200$ & $25 ; 50$ \\
\hline Wen et al. (2014) [59] & Mouse primary neurons & $25-400$ & $25-200$ & $25-400$ & 25 \\
\hline Wen et al. (2014) [59] & Human iPSC derived neurons & & 50 & 50 & & 47 \\
\hline Freibaum et al. (2015) [62] & Drosophila & 50 & & 50 & \\
\hline Jovičić et al. (2015) [81] & Saccharomyces cerevisiae & $50 ; 100$ & 50 & 50 & 50 & 30 \\
\hline Tao et al. (2015) [75] & HEK293 / NSC34 cells & 30 & 30 & 30 & 30 \\
\hline Yamakawa et al. (2015) [84] & Neuro-2a cells & 100 & 100 & 100 & 100 & 100 \\
\hline Yang et al. (2015) [85] & Drosophila & 80 & 80 & 80 & & \\
\hline Boeynaems et al. (2016) [82] & Drosophila & 50 & $25 ; 50$ & 50 & 50 & \\
\hline Kanekura et al. (2016) [76] & NSC34 cells & $20^{*}$ & $20^{*}$ & $20^{*}$ & & \\
\hline Lopez-Gonzalez et al. (2016) [77] & Human iPSC derived motor neurons & 80 & & 80 & & \\
\hline Lee et al. (2016) [79] & Neuro-2a cells & 50 & 50 & 50 & 50 & 47 \\
\hline Lee et al. (2016) [79] & Drosophila & 50 & 50 & 50 & 50 & 47 \\
\hline
\end{tabular}

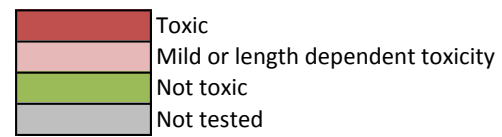

Table 3: Comparison of studies that compare the toxicity of individual DPRs in different model systems.

Numbers indicate the repeat length(s) tested in the study, note: in some studies the dipeptide proteins are epitope tagged.

*Peptides were exogenously applied to cells rather than overexpressed. Note poly-GA was found to be toxic in primary neurons [72-75] but these studies were excluded from the table as they do not compare to other DPRs. 


\section{Acknowledgements}

Funding: TGM is supported by a Brain Research Trust studentship; LP is supported by the Wellcome Trust [098565/Z/12/Z]; AMI is supported by Alzheimer's Research UK, the UK Motor Neurone Disease Association and the European Research Council. 


\section{References}

1. DeJesus-Hernandez M, Mackenzie IR, Boeve BF, Boxer AL, Baker M, Rutherford NJ, Nicholson AM, Finch NA, Flynn H, Adamson J, et al.:

Expanded GGGGCC hexanucleotide repeat in noncoding region of C9ORF72 causes chromosome 9p-linked FTD and ALS. Neuron 2011, 72:245-56.

2. Renton AE, Majounie E, Waite A, Simón-Sánchez J, Rollinson S, Gibbs JR, Schymick JC, Laaksovirta H, van Swieten JC, Myllykangas L, et al.: A hexanucleotide repeat expansion in C9ORF72 is the cause of chromosome 9p21-linked ALS-FTD. Neuron 2011, 72:257-68.

3. Beck J, Poulter M, Hensman D, Rohrer JD, Mahoney CJ, Adamson G, Campbell T, Uphill J, Borg A, Fratta P, et al.: Large C9orf72 hexanucleotide repeat expansions are seen in multiple neurodegenerative syndromes and are more frequent than expected in the UK population. Am. J. Hum. Genet. 2013, 92:345-53.

4. van Blitterswijk M, DeJesus-Hernandez M, Niemantsverdriet E, Murray ME, Heckman MG, Diehl NN, Brown PH, Baker MC, Finch NA, Bauer PO, et al.: Association between repeat sizes and clinical and pathological characteristics in carriers of C9ORF72 repeat expansions (Xpansize-72): a cross-sectional cohort study. Lancet Neurol. 2013, 12:978-988.

5. van Blitterswijk M, DeJesus-Hernandez M, Rademakers R: How do C9ORF72 repeat expansions cause amyotrophic lateral sclerosis and frontotemporal dementia: can we learn from other noncoding repeat expansion disorders? Curr. Opin. Neurol. 2012, 25:689-700.

6. Murray ME, DeJesus-Hernandez M, Rutherford NJ, Baker M, Duara R, GraffRadford NR, Wszolek ZK, Ferman TJ, Josephs KA, Boylan KB, et al.: Clinical and neuropathologic heterogeneity of c9FTD/ALS associated with hexanucleotide repeat expansion in C9ORF72. Acta Neuropathol. 2011, 122:673-690. 
7. Xiao S, MacNair L, McGoldrick P, McKeever PM, McLean JR, Zhang M, Keith J, Zinman L, Rogaeva E, Robertson J: Isoform-specific antibodies reveal distinct subcellular localizations of C9orf72 in amyotrophic lateral sclerosis. Ann. Neurol. 2015, 78:568-83.

8. Belzil V V, Bauer PO, Prudencio M, Gendron TF, Stetler CT, Yan IK, Pregent L, Daughrity L, Baker MC, Rademakers R, et al.: Reduced C9orf72 gene expression in c9FTD/ALS is caused by histone trimethylation, an epigenetic event detectable in blood. Acta Neuropathol. 2013, 126:895905.

9. Ciura S, Lattante S, Le Ber I, Latouche M, Tostivint H, Brice A, Kabashi E: Loss of function of C9orf72 causes motor deficits in a zebrafish model of amyotrophic lateral sclerosis. Ann. Neurol. 2013, 74:180-7.

10. Xi Z, Zinman L, Moreno D, Schymick J, Liang Y, Sato C, Zheng Y, Ghani M, Dib S, Keith J, et al.: Hypermethylation of the CpG island near the G4C2 repeat in ALS with a C9orf72 expansion. Am. J. Hum. Genet. 2013, 92:9819.

11. Waite AJ, Bäumer D, East S, Neal J, Morris HR, Ansorge O, Blake DJ: Reduced C9orf72 protein levels in frontal cortex of amyotrophic lateral sclerosis and frontotemporal degeneration brain with the C9ORF72 hexanucleotide repeat expansion. Neurobiol. Aging 2014, 35:1779.e51779.e13.

12. Fratta P, Poulter M, Lashley T, Rohrer JD, Polke JM, Beck J, Ryan N, Hensman D, Mizielinska S, Waite AJ, et al.: Homozygosity for the C9orf72 GGGGCC repeat expansion in frontotemporal dementia. Acta Neuropathol. 2013, 126:401-409.

13. Gijselinck I, Van Langenhove T, van der Zee J, Sleegers K, Philtjens S, Kleinberger G, Janssens J, Bettens K, Van Cauwenberghe C, Pereson S, et al.: A C9orf72 promoter repeat expansion in a Flanders-Belgian cohort with disorders of the frontotemporal lobar degeneration-amyotrophic 
lateral sclerosis spectrum: a gene identification study. Lancet Neurol. 2012, 11:54-65.

14. Sivadasan R, Hornburg D, Drepper C, Frank N, Jablonka S, Hansel A, Lojewski X, Sterneckert J, Hermann A, Shaw PJ, et al.: C9ORF72 interaction with cofilin modulates actin dynamics in motor neurons. Nat. Neurosci. 2016, doi:10.1038/nn.4407.

15. Liu EY, Russ J, Wu K, Neal D, Suh E, McNally AG, Irwin DJ, Van Deerlin VM, Lee EB: C9orf72 hypermethylation protects against repeat expansionassociated pathology in ALS/FTD. Acta Neuropathol. 2014, 128:525-41.

16. Xi Z, Zhang M, Bruni AC, Maletta RG, Colao R, Fratta P, Polke JM, Sweeney MG, Mudanohwo E, Nacmias B, et al.: The C9orf72 repeat expansion itself is methylated in ALS and FTLD patients. Acta Neuropathol. 2015, 129:71527.

17. Haeusler AR, Donnelly CJ, Periz G, Simko EAJ, Shaw PG, Kim M-S, Maragakis NJ, Troncoso JC, Pandey A, Sattler R, et al.: C9orf72 nucleotide repeat structures initiate molecular cascades of disease. Nature 2014, 507:195-200.

18. Harms MB, Cady J, Zaidman C, Cooper P, Bali T, Allred P, Cruchaga C, Baughn M, Libby RT, Pestronk $A$, et al.: Lack of C9ORF72 coding mutations supports a gain of function for repeat expansions in amyotrophic lateral sclerosis. Neurobiol. Aging 2013, 34:2234.e13-2234.e19.

19. Liu F, Liu Q, Lu CX, Cui B, Guo XN, Wang RR, Liu MS, Li XG, Cui L, Zhang X: Identification of a novel loss-of-function C9orf72 splice site mutation in a patient with amyotrophic lateral sclerosis. Neurobiol. Aging 2016, doi:10.1016/j.neurobiolaging.2016.07.027.

20. Mizielinska S, Isaacs AM: C9orf72 amyotrophic lateral sclerosis and frontotemporal dementia: gain or loss of function? Curr. Opin. Neurol. 2014, 27:515-23. 
21. Levine TP, Daniels RD, Gatta AT, Wong LH, Hayes MJ: The product of C9orf72, a gene strongly implicated in neurodegeneration, is structurally related to DENN Rab-GEFs. Bioinformatics 2013, 29:499-503.

22. Yang M, Liang C, Swaminathan K, Herrlinger S, Lai F, Shiekhattar R, Chen JF: A C9ORF72/SMCR8-containing complex regulates ULK1 and plays a dual role in autophagy. Sci. Adv. 2016, 2.

23. Sellier C, Campanari M-L, Julie Corbier C, Gaucherot A, Kolb-Cheynel I, Oulad-Abdelghani M, Ruffenach F, Page A, Ciura S, Kabashi E, et al.: Loss of C9ORF72 impairs autophagy and synergizes with polyQ Ataxin-2 to induce motor neuron dysfunction and cell death. EMBO J. 2016, 35:127697.

24. Blokhuis AM, Koppers M, Groen EJN, van den Heuvel DMA, Dini Modigliani S, Anink JJ, Fumoto K, van Diggelen F, Snelting $A$, Sodaar $P$, et al.:

Comparative interactomics analysis of different ALS-associated proteins identifies converging molecular pathways. Acta Neuropathol. 2016, 132:175-96.

25. Sullivan PM, Zhou X, Robins AM, Paushter DH, Kim D, Smolka MB, Hu F: The ALS/FTLD associated protein C9orf72 associates with SMCR8 and WDR41 to regulate the autophagy-lysosome pathway. Acta Neuropathol. Commun. 2016, 4:51.

26. Xiao S, MacNair L, McLean J, McGoldrick P, McKeever P, Soleimani S, Keith J, Zinman L, Rogaeva E, Robertson J: C9orf72 isoforms in Amyotrophic Lateral Sclerosis and Frontotemporal Lobar Degeneration. Brain Res. 2016, 1647:43-49.

27. Amick J, Roczniak-Ferguson A, Ferguson SM: C9orf72 binds SMCR8, localizes to lysosomes and regulates mTORC1 signaling. Mol. Biol. Cell 2016, doi:10.1091/mbc.E16-01-0003.

28. Webster CP, Smith EF, Bauer CS, Moller A, Hautbergue GM, Ferraiuolo L, 
Myszczynska MA, Higginbottom A, Walsh MJ, Whitworth AJ, et al.: The C9orf72 protein interacts with Rab1a and the ULK1 complex to regulate initiation of autophagy. EMBO J 2016, doi:10.15252/embj.201694401.

29. Farg MA, Sundaramoorthy V, Sultana JM, Yang S, Atkinson RAK, Levina V, Halloran MA, Gleeson PA, Blair IP, Soo KY, et al.: C9ORF72, implicated in amytrophic lateral sclerosis and frontotemporal dementia, regulates endosomal trafficking. Hum. Mol. Genet. 2014, 23:3579-95.

30. Therrien M, Rouleau GA, Dion PA, Parker JA: Deletion of C9ORF72 results in motor neuron degeneration and stress sensitivity in C. elegans. PLoS One 2013, 8:e83450.

31. Koppers M, Blokhuis AM, Westeneng H-J, Terpstra ML, Zundel CAC, Vieira de Sá R, Schellevis RD, Waite AJ, Blake DJ, Veldink JH, et al.: C9orf72 ablation in mice does not cause motor neuron degeneration or motor deficits. Ann. Neurol. 2015, 78:426-38.

32. Sudria-Lopez E, Koppers M, de Wit M, van der Meer C, Westeneng H-J, Zundel CAC, Youssef SA, Harkema L, de Bruin A, Veldink JH, et al.: Full ablation of C9orf72 in mice causes immune system-related pathology and neoplastic events but no motor neuron defects. Acta Neuropathol. $2016,132: 145-147$.

33. O’Rourke JG, Bogdanik L, Yáñez A, Lall D, Wolf AJ, Muhammad AKMG, Ho $\mathrm{R}$, Carmona S, Vit JPP, Zarrow J, et al.: C9orf72 is required for proper macrophage and microglial function in mice. Science (80-. ). 2016, 351:1324-1329.

34. Lagier-Tourenne C, Baughn M, Rigo F, Sun S, Liu P, Li H-R, Jiang J, Watt AT, Chun S, Katz M, et al.: Targeted degradation of sense and antisense C9orf72 RNA foci as therapy for ALS and frontotemporal degeneration. Proc. Natl. Acad. Sci. U. S. A. 2013, 110:E4530-9.

35. Burberry A, Suzuki N, Wang J-Y, Moccia R, Mordes DA, Stewart MH, Suzuki- 
Uematsu S, Ghosh S, Singh A, Merkle FT, et al.: Loss-of-function mutations in the C9ORF72 mouse ortholog cause fatal autoimmune disease. Sci. Transl. Med. 2016, 8:347ra93.

36. Jiang J, Zhu Q, Gendron TFF, Saberi S, McAlonis-Downes M, Seelman A, Stauffer JEE, Jafar-Nejad P, Drenner K, Schulte D, et al.: Gain of Toxicity from ALS/FTD-Linked Repeat Expansions in C9ORF72 Is Alleviated by Antisense Oligonucleotides Targeting GGGGCC-Containing RNAs. Neuron 2016, 90:535-550.

37. Atanasio A, Decman V, White D, Ramos M, Ikiz B, Lee H-C, Siao C-J, Brydges S, LaRosa E, Bai Y, et al.: C9orf72 ablation causes immune dysregulation characterized by leukocyte expansion, autoantibody production, and glomerulonephropathy in mice. Sci. Rep. 2016, 6:23204.

38. Heneka MT, Kummer MP, Latz E: Innate immune activation in neurodegenerative disease. Nat. Rev. Immunol. 2014, 14:463-477.

39. Wojciechowska M, Krzyzosiak WJ: Cellular toxicity of expanded RNA repeats: focus on RNA foci. Hum. Mol. Genet. 2011, 20:3811-21.

40. Mizielinska S, Lashley T, Norona FE, Clayton EL, Ridler CE, Fratta P, Isaacs AM: C9orf72 frontotemporal lobar degeneration is characterised by frequent neuronal sense and antisense RNA foci. Acta Neuropathol. 2013, 126:845-57.

41. Sareen D, O'Rourke JG, Meera P, Muhammad AKMG, Grant S, Simpkinson M, Bell S, Carmona S, Ornelas L, Sahabian A, et al.: Targeting RNA foci in iPSC-derived motor neurons from ALS patients with a C9ORF72 repeat expansion. Sci. Transl. Med. 2013, 5:208ra149.

42. Cooper-Knock J, Walsh MJ, Higginbottom A, Robin Highley J, Dickman MJ, Edbauer D, Ince PG, Wharton SB, Wilson SA, Kirby J, et al.: Sequestration of multiple RNA recognition motif-containing proteins by $\mathrm{C} 9$ orf72 repeat expansions. Brain 2014, 137:2040-51. 
43. Zu T, Liu Y, Bañez-Coronel M, Reid T, Pletnikova O, Lewis J, Miller TM, Harms MB, Falchook AE, Subramony SH, et al.: RAN proteins and RNA foci from antisense transcripts in C9ORF72 ALS and frontotemporal dementia. Proc. Natl. Acad. Sci. U. S. A. 2013, 110:E4968-77.

44. Almeida S, Gascon E, Tran H, Chou HJ, Gendron TF, Degroot S, Tapper AR, Sellier C, Charlet-Berguerand N, Karydas A, et al.: Modeling key pathological features of frontotemporal dementia with C9ORF72 repeat expansion in iPSC-derived human neurons. Acta Neuropathol. 2013, 126:385-99.

45. Lee Y-B, Chen H-J, Peres JN, Gomez-Deza J, Attig J, Stalekar M, Troakes C, Nishimura AL, Scotter EL, Vance C, et al.: Hexanucleotide repeats in ALS/FTD form length-dependent RNA foci, sequester RNA binding proteins, and are neurotoxic. Cell Rep. 2013, 5:1178-86.

46. Donnelly CJJ, Zhang P-W, Pham JTT, Haeusler ARR, Mistry NAA, Vidensky S, Daley ELL, Poth EMM, Hoover B, Fines DMM, et al.: RNA toxicity from the ALS/FTD C9ORF72 expansion is mitigated by antisense intervention. Neuron 2013, 80:415-28.

47. Gendron TF, Bieniek KF, Zhang Y-J, Jansen-West K, Ash PEA, Caulfield T, Daughrity L, Dunmore JH, Castanedes-Casey M, Chew J, et al.: Antisense transcripts of the expanded C9ORF72 hexanucleotide repeat form nuclear RNA foci and undergo repeat-associated non-ATG translation in c9FTD/ALS. Acta Neuropathol. 2013, 126:829-844.

48. Cooper-Knock J, Higginbottom A, Stopford MJ, Highley JR, Ince PG, Wharton SB, Pickering-Brown S, Kirby J, Hautbergue GM, Shaw PJ: Antisense RNA foci in the motor neurons of C9ORF72-ALS patients are associated with TDP-43 proteinopathy. Acta Neuropathol. 2015, 130:63-75.

49. Haeusler AR, Donnelly CJ, Rothstein JD: The expanding biology of the C9orf72 nucleotide repeat expansion in neurodegenerative disease. Nat. Rev. Neurosci. 2016, 17:383-395. 
50. Ash PEA, Bieniek KF, Gendron TF, Caulfield T, Lin W-L, Dejesus-Hernandez M, van Blitterswijk MM, Jansen-West K, Paul JW, Rademakers R, et al.: Unconventional translation of C9ORF72 GGGGCC expansion generates insoluble polypeptides specific to c9FTD/ALS. Neuron 2013, 77:639-46.

51. Mori K, Weng S-M, Arzberger T, May S, Rentzsch K, Kremmer E, Schmid B, Kretzschmar HA, Cruts M, Van Broeckhoven C, et al.: The C9orf72 GGGGCC repeat is translated into aggregating dipeptide-repeat proteins in FTLD/ALS. Science 2013, 339:1335-8.

52. Mackenzie IR, Arzberger T, Kremmer E, Troost D, Lorenzl S, Mori K, Weng SM, Haass C, Kretzschmar HA, Edbauer D, et al.: Dipeptide repeat protein pathology in C9ORF72 mutation cases: clinico-pathological correlations. Acta Neuropathol. 2013, 126:859-79.

53. Mackenzie IRA, Frick P, Grässer FA, Gendron TF, Petrucelli L, Cashman NR, Edbauer D, Kremmer E, Prudlo J, Troost D, et al.: Quantitative analysis and clinico-pathological correlations of different dipeptide repeat protein pathologies in C9ORF72 mutation carriers. Acta Neuropathol. 2015, 130:845-61.

54. Davidson Y, Robinson AC, Liu X, Wu D, Troakes C, Rollinson S, MasudaSuzukake M, Suzuki G, Nonaka T, Shi J, et al.: Neurodegeneration in frontotemporal lobar degeneration and motor neurone disease associated with expansions in C9orf72 is linked to TDP-43 pathology and not associated with aggregated forms of dipeptide repeat proteins. Neuropathol. Appl. Neurobiol. 2016, 42:242-54.

55. Davidson YS, Barker H, Robinson AC, Thompson JC, Harris J, Troakes C, Smith B, Al-Saraj S, Shaw C, Rollinson S, et al.: Brain distribution of dipeptide repeat proteins in frontotemporal lobar degeneration and motor neurone disease associated with expansions in C9ORF72. Acta Neuropathol. Commun. 2014, 2:70.

56. Gendron TF, van Blitterswijk M, Bieniek KF, Daughrity LM, Jiang J, Rush BK, 
Pedraza O, Lucas JA, Murray ME, Desaro P, et al.: Cerebellar c9RAN proteins associate with clinical and neuropathological characteristics of C9ORF72 repeat expansion carriers. Acta Neuropathol. 2015, 130:559-73.

57. Zu T, Gibbens B, Doty NS, Gomes-Pereira M, Huguet A, Stone MD, Margolis J, Peterson M, Markowski TW, Ingram MAC, et al.: Non-ATG-initiated translation directed by microsatellite expansions. Proc. Natl. Acad. Sci. U. S. A. $2011,108: 260-5$.

58. Xu Z, Poidevin M, Li X, Li Y, Shu L, Nelson DL, Li H, Hales CM, Gearing M, Wingo TS, et al.: Expanded GGGGCC repeat RNA associated with amyotrophic lateral sclerosis and frontotemporal dementia causes neurodegeneration. Proc. Natl. Acad. Sci. U. S. A. 2013, 110:7778-83.

59. Wen X, Tan W, Westergard T, Krishnamurthy K, Markandaiah SS, Shi Y, Lin S, Shneider NA, Monaghan J, Pandey UB, et al.: Antisense proline-arginine RAN dipeptides linked to C9ORF72-ALS/FTD form toxic nuclear aggregates that initiate in vitro and in vivo neuronal death. Neuron 2014, 84:1213-25.

60. Kramer NJ, Carlomagno Y, Zhang Y-J, Almeida S, Cook CN, Gendron TF, Prudencio M, Van Blitterswijk M, Belzil V, Couthouis J, et al.: Spt4 selectively regulates the expression of C9orf72 sense and antisense mutant transcripts. Science (80-. ). 2016, 353.

61. Mizielinska S, Grönke S, Niccoli T, Ridler CE, Clayton EL, Devoy A, Moens T, Norona FE, Woollacott IOC, Pietrzyk J, et al.: C9orf72 repeat expansions cause neurodegeneration in Drosophila through arginine-rich proteins. Science 2014, 16:1131-5.

62. Freibaum BD, Lu Y, Lopez-Gonzalez R, Kim NC, Almeida S, Lee K-H, Badders N, Valentine M, Miller BL, Wong PC, et al.: GGGGCC repeat expansion in C9orf72 compromises nucleocytoplasmic transport. Nature 2015, 525:129-133. 
63. Burguete AS, Almeida S, Gao F-B, Kalb R, Akins MR, Bonini NM, Alami N, Smith R, Carrasco M, Williams $L$, et al.: GGGGCC microsatellite RNA is neuritically localized, induces branching defects, and perturbs transport granule function. Elife 2015, 4:e08881.

64. Chew J, Gendron TF, Prudencio M, Sasaguri H, Zhang Y-J, CastanedesCasey M, Lee CW, Jansen-West K, Kurti A, Murray ME, et al.:

Neurodegeneration. C9ORF72 repeat expansions in mice cause TDP-43 pathology, neuronal loss, and behavioral deficits. Science 2015, 348:1151-4.

65. O'Rourke JG, Bogdanik L, Muhammad AKMG, Gendron TF, Kim KJ, Austin A, Cady J, Liu EY, Zarrow J, Grant S, et al.: C9orf72 BAC Transgenic Mice Display Typical Pathologic Features of ALS/FTD. Neuron 2015, 88:892901.

66. Peters OM, Cabrera GT, Tran H, Gendron TF, McKeon JE, Metterville J, Weiss A, Wightman N, Salameh J, Kim J, et al.: Human C9ORF72 Hexanucleotide Expansion Reproduces RNA Foci and Dipeptide Repeat Proteins but Not Neurodegeneration in BAC Transgenic Mice. Neuron 2015, 88:902-9.

67. Liu Y, Pattamatta A, Zu T, Reid T, Bardhi O, Borchelt DR, Yachnis AT, Ranum LPW, Al-Sarraj S, King A, et al.: C9orf72 BAC Mouse Model with Motor Deficits and Neurodegenerative Features of ALS/FTD. Neuron 2016, 90:521-534.

68. Ishimura R, Nagy G, Dotu I, Zhou H, Yang X-L, Schimmel P, Senju S, Nishimura Y, Chuang JH, Ackerman SL: RNA function. Ribosome stalling induced by mutation of a CNS-specific tRNA causes neurodegeneration. Science 2014, 345:455-9.

69. Baldwin KR, Godena VK, Hewitt VL, Whitworth AJ: Axonal transport defects are a common phenotype in Drosophila models of ALS. Hum. Mol. Genet. 2016, 25:ddw105. 
70. Tran H, Almeida S, Moore J, Gendron TF, Chalasani U, Lu Y, Du X, Nickerson JA, Petrucelli L, Weng Z, et al.: Differential Toxicity of Nuclear RNA Foci versus Dipeptide Repeat Proteins in a Drosophila Model of C9ORF72 FTDIALS. Neuron 2015, 87:1207-14.

71. Zhang K, Donnelly CJ, Haeusler AR, Grima JC, Machamer JB, Steinwald P, Daley EL, Miller SJ, Cunningham KM, Vidensky S, et al.: The C9orf72 repeat expansion disrupts nucleocytoplasmic transport. Nature 2015, 525:56-61.

72. Zhang Y-J, Jansen-West K, Xu Y-F, Gendron TF, Bieniek KF, Lin W-L, Sasaguri $H$, Caulfield T, Hubbard J, Daughrity L, et al.: Aggregation-prone c9FTD/ALS poly(GA) RAN-translated proteins cause neurotoxicity by inducing ER stress. Acta Neuropathol. 2014, 128:505-24.

73. May S, Hornburg D, Schludi MH, Arzberger T, Rentzsch K, Schwenk BM, Grässer FA, Mori K, Kremmer E, Banzhaf-Strathmann J, et al.: C9orf72 FTLD/ALS-associated Gly-Ala dipeptide repeat proteins cause neuronal toxicity and Unc119 sequestration. Acta Neuropathol. 2014, 128:485-503.

74. Zhang Y-J, Gendron TF, Grima JC, Sasaguri H, Jansen-West K, Xu Y-F, Katzman RB, Gass J, Murray ME, Shinohara M, et al.: C9ORF72 poly(GA) aggregates sequester and impair HR23 and nucleocytoplasmic transport proteins. Nat. Neurosci. 2016, advance on:668-677.

75. Chang Y-J, Jeng U-S, Chiang Y-L, Hwang I-S, Chen Y-R: The GlycineAlanine Dipeptide Repeat from C9orf72 Hexanucleotide Expansions Forms Toxic Amyloids Possessing Cell-to-Cell Transmission Properties. J. Biol. Chem. 2016, 291:4903-4911.

76. Tao Z, Wang H, Xia Q, Li K, Jiang X, Xu G, Wang G, Ying Z: Nucleolar stress and impaired stress granule formation contribute to C9orf72 RAN translation-induced cytotoxicity. Hum. Mol. Genet. 2015, doi:10.1093/hmg/ddv005.

77. Kanekura K, Yagi T, Cammack AJ, Mahadevan J, Kuroda M, Harms MB, 
Miller TM, Urano F: Poly-dipeptides encoded by the C9ORF72 repeats block global protein translation. Hum. Mol. Genet. 2016, doi:10.1093/hmg/ddw052.

78. Lopez-Gonzalez R, Lu Y, Gendron TF, Karydas A, Tran H, Yang D, Petrucelli L, Miller BL, Almeida S, Gao F-B: Poly(GR) in C9ORF72-Related ALS/FTD Compromises Mitochondrial Function and Increases Oxidative Stress and DNA Damage in iPSC-Derived Motor Neurons. Neuron 2016, 92:383391.

79. Lin Y, Mori E, Kato M, Xiang S, Wu L, Kwon I, McKnight SL, Ash PE, Bieniek KF, Gendron TF, et al.: Toxic PR Poly-Dipeptides Encoded by the C9orf72 Repeat Expansion Target LC Domain Polymers. Cell 2016, 167:789802.e12.

80. Lee K-H, Zhang P, Kim HJ, Mitrea DM, Sarkar M, Freibaum BD, Cika J, Coughlin M, Messing J, Molliex A, et al.: C9orf72 Dipeptide Repeats Impair the Assembly, Dynamics, and Function of Membrane-Less Organelles. Cell 2016, 167:774-788.e17.

81. Kwon I, Xiang S, Kato M, Wu L, Theodoropoulos P, Wang T, Kim J, Yun J, Xie Y, McKnight SL: Poly-dipeptides encoded by the C9ORF72 repeats bind nucleoli, impede RNA biogenesis, and kill cells. Science 2014, 345:11391145.

82. Jovičić A, Mertens J, Boeynaems S, Bogaert E, Chai N, Yamada SB, Paul JW, Sun S, Herdy JR, Bieri G, et al.: Modifiers of C9orf72 dipeptide repeat toxicity connect nucleocytoplasmic transport defects to FTD/ALS. Nat. Neurosci. 2015, 18:1226-1229.

83. Boeynaems S, Bogaert E, Michiels E, Gijselinck I, Sieben A, Jovičić A, De Baets G, Scheveneels W, Steyaert J, Cuijt I, et al.: Drosophila screen connects nuclear transport genes to DPR pathology in c9ALS/FTD. Sci. Rep. 2016, 6:20877. 
84. Nixon RA: The role of autophagy in neurodegenerative disease. Nat. Med. 2013, 19:983-997.

85. Yamakawa M, Ito D, Honda T, Kubo K, Noda M, Nakajima K, Suzuki N: Characterization of the dipeptide repeat protein in the molecular pathogenesis of c9FTD/ALS. Hum. Mol. Genet. 2015, 24:1630-45.

86. Yang D, Abdallah A, Li Z, Lu Y, Almeida S, Gao F-B: FTD/ALS-associated poly(GR) protein impairs the Notch pathway and is recruited by poly(GA) into cytoplasmic inclusions. Acta Neuropathol. 2015, doi:10.1007/s00401015-1448-6.

87. Wojciechowska M, Olejniczak M, Galka-Marciniak P, Jazurek M, Krzyzosiak WJ: RAN translation and frameshifting as translational challenges at simple repeats of human neurodegenerative disorders. Nucleic Acids Res. 2014, 42:11849-64. 